\title{
Responses
}

\section{Valuing Modern Contract Scholarship}

\author{
Ian Ayres $^{\dagger}$
}

\section{INTRODUCTION}

Eric Posner has written a thoughtful and provocative indictment of the modern economic analysis of contracts. His essay makes two central claims about the failings of scholars "to produce an "economic theory.", Specifically, Posner claims that the economic approach "does not explain the current system of contract law" and that it does not "provide a solid basis for criticizing and reforming contract law.", In other words, Posner claims that modern scholarship fails as either a descriptive or a normative theory, in that it fails to give an account of what current law is or what efficient law should be.

The descriptive criticism deserves only brief comment. Although he claims that modern scholarship has failed to achieve "what its proponents set out as the measure of success," ${ }^{3}$ Posner sadly distorts reality by claiming that the leading scholars have been engaged in an attempt to use economic theory to predict the content of current legal rules. This is a straw man. Of course, decades ago this was the project of Richard Posner. ${ }^{4}$ But the thought that efficiency analysis would provide a mechanism to predict the details of current doctrine is a serious misreading of the aims of modern scholarship.

$\dagger$ William K. Townsend Professor, Yale Law School, ian.ayres@yale.edu. Alan Schwartz provided helpful comments.

1. Eric A. Posner, Economic Analysis of Contract Law After Three Decades: Success or Failure?, 112 YALE L.J. 829, 830 (2003).

2. Id.

3. Id. at 879; see also id. at 831 ("[T] contract law [was] to provide an explanation of existing legal rules . . ..").

4. See Richard A. POSNER, ECONOMIC ANALYSiS OF LAW (3d ed. 1986). 
Posner himself concedes that Steven Shavell, Charles Goetz, Robert Scott, Alan Schwartz, Richard Epstein, Alan Sykes, Michelle White, Richard Craswell, Avery Katz, Eric Rasmusen, and I have not been engaged in using efficiency analysis to predict the content of current law. ${ }^{5}$ Posner's essay would be much stronger if he jettisoned the descriptive criticism.

Posner's normative claim that modern scholarship fails "to provide a basis for criticizing or defending those rules" and deserves a more extended comment. Posner argues that the economic models are either too simple or too complex to yield persuasive advice about what the law should be. The simple models "examine only one or two margins of contractual behavior" ${ }^{\prime \prime}$ and hence are not well suited to assess whether overall efficiency would be achieved by a particular rule. And because the more complex models "examine a greater variety of behavior, or because they rely on more complicated ideas, such as information asymmetry ... [they] often ... fail because they are indeterminate." ${ }^{8}$ The more realistic models often suggest that the optimal content of contract law will turn on details of the underlying environment that will be difficult for lawmakers to ascertain.

This normative critique is an important concern. Instead of pursuing the descriptive claim, the coterie of modern contract scholars has aspired to assess the efficiency of alternative contract rules. And regardless of the scholars' intent, scholarship that fails to provide a perspective that would aid in the normative enterprise would be ultimately unsuccessful.

This normative critique is also related to Posner's suggestion that modern economic analysis of contract law seems to have run its course. He is "skeptic[al] about how much additional value [it] has to offer to understanding contract law today." Let's call this the evolutionary critique. The idea that economic analysis has intellectually painted itself into a corner parallels analogous claims made about game theory more generally - that the models are either too reductive or too indeterminate to be of practical normative value. ${ }^{10}$ An unmistakable tone of pessimism pervades Posner's prose.

I concede that much of the modern scholarship is either based on reductive models or yields normative results that are contingent on particular parameter values of the underlying environment. But I see much more normative value in the contributions of the last two decades. Maybe

5. Posner, supra note 1, at 852 ("The charge of descriptive failure will not surprise scholars familiar with the literature on economic analysis of contract law.").

6. Id. at 831 .

7. Id. at 853 .

8. Id.

9. Id. at 830 .

10. Franklin M. Fisher, Games Economists Play: A Noncooperative View, 20 RAND J. ECON. $113(1989)$ 
the largest contribution is in destabilizing false confidence in prior analysis. If prior consensus holds that default rules should simply be set to provide the substantive provision that most contractors want, then a reductive model that simply provides a counterexample can represent an important contribution. Economists become famous for proving "impossibility theorems," but "possibility" theorems are also valuable.

A lot turns then on what constitutes "a basis for criticizing or defending" contract rules. ${ }^{12}$ Modern scholarship has succeeded in supplanting unsupportable beliefs with a more supportable agnosticism. If prior consensus wrongly holds that a particular contractual rule worked across the broad range of contractual settings, then an article that shows that the efficiency of the rule's operation is affected by some underlying bargaining parameter is important whether or not lawmakers can easily assess the size of the crucial parameter. Showing that prior beliefs were overly determinate constitutes a basis for criticism. It is slightly ironic that Posner, in what is essentially a "trashing" piece, refuses to see the value of "trashing" itself. ${ }^{13}$

If agnosticism were the only contribution of the modern scholarship, it would be reasonable to worry that the field would quickly paint itself into a corner. But Posner himself concedes:

[E]ven if economic models cannot generate a determinate optimal contract law, they helpfully identify the costs and benefits of different legal rules.... [E]ven if economic analysis cannot determine the magnitude of these costs and benefits, and the extent to which they offset or interact with each other, the judge who knows about them is more likely to make a wise decision than a judge who does not. ${ }^{14}$

Posner, however, immediately rejects the qualitative value that the models might have for lawmakers:

This defense has an air of plausibility but also distressingly open-ended and unambitious implications. The last decade has witnessed a piling on of relevant factors, but no increasing clarity about the function of contract law, and a wise judge might, in order

11. See Kenneth J. Arrow, Social Choice and Individual Values (1951); Omri BenShahar, The Tentative Case Against Flexibility in Commercial Law, 66 U. CHI. L. REV. 781 (1999); Steven Shavell, Strict Liability Versus Negligence, 9 J. LEGAL STUD. 1 (1980).

12. Posner, supra note 1, at 831

13. See Mark G. Kelman, Trashing, 36 STAN. L. REV. 293 (1984).

14. Posner, supra note 1 , at $854-55$ 
to avoid paralysis, simply ignore them. But the scholarship itself is mute about its own weaknesses. ${ }^{15}$

It is here that Posner and I part company. First, the scholarship has not been mute about either the indeterminacy concern or the "piling on" of factors. ${ }^{16}$ For example, Rob Gertner and I have shown in a simple model that an optimal legal rule can turn on subtle differences in the parties' costs of contracting, and we expressly acknowledge that "[w]hen the parties' knowledge is not symmetric ... choosing the efficient contract rule can entail an extraordinarily complex analysis-which depends on subtle pieces of information that lawmakers are unlikely to know." $" 17$

But more importantly, Posner's disavowal of qualitative value turns on a quasi-empirical assessment that there has been no increasing clarity about which factors should dominate. I disagree. In particular settings, lawmakers can reasonably conclude that one or another problem (such as promisee overreliance or promisor ignorance) is the most salient. Using the insights of modern scholarship, they can fashion with greater clarity laws that further their consequential objectives. But our disagreement is largely an empirical one, and the proof is in the pudding. So let me turn to my take on the more particularized successes of the modern economic analysis of contract.

15. Id.

16. See lan Ayres \& Kristin Madison, Threatening Inefficient Performance of Injunctions and Contracts, 148 U. PA. L. REV. 45, 56 (1999) ("[I]t is nigh-on impossible to construct a single damage rule that will induce efficient behavior along all possible dimensions...."); id. at 87 (" $[\mathrm{L}] \mathrm{aw}$ and economics scholars in the last decade have found it increasingly difficult to conjure a single damage measure that induces both sides to behave efficiently on a variety of dimensions ...."); id. at 91 (discussing twelve different efficiency effects caused by a policy that deters threats of inefficient performance).

17. Ian Ayres \& Robert Gertner, Strategic Contractual Inefficiency and the Optimal Choice of Legal Rules, 101 YALE L.J. 729, 765-66 (1991). In our article, we identify six different legal regimes (including both default and mandatory rules) that would be optimal for alternative values of particular underlying transaction cost parameters. Id. at 751-59.

Bruce Ackerman (foreshadowing Posner's claim) told me that after reading this article lawmakers should feel liberated from the constraint of pursuing efficiency. We went on to emphasize, however:

This practical indeterminacy of our model should not ... be taken to undermine the appropriateness of either economic modeling or the goal of choosing efficient legal rules. Our model suggests that the task of pursuing any other normative theory of social welfare will be just as complex, and therefore will encounter similar forms of indeterminacy.

Id. at 765-66. It is important to distinguish two types of indeterminacy. Alan Schwartz has persuasively argued that the courts should not imply contractual terms that are contingent on unverifiable terms because courts by assumption will not be able to determine whether in fact the contingency has occurred. See Alan Schwartz, The Default Rule Paradigm and the Limits of Contract Law, 3 S. CAL. INTERDISC. L.J. 389, 404-06 (1993). However, even after restricting one's attention to default provisions that are contingent upon verifiable information, the choice of the optimal default can be indeterminate, because the choice of rule itself may depend on factors (such as the cost of contracting) that a court may have difficulty observing or verifying. 


\section{SOME LESSONS OF ECONOMIC ANALYSIS}

I claim, counter to Posner, that modern scholarship has produced important normative results-clarifying when contract rules should be mandatory, illuminating a richer theory of default rule choice, and underscoring the importance of renegotiation.

\section{A. Making Visible the Default/Mandatory Rule Dichotomy}

There is a certain tyranny of time. A scholar's outlook is in some way irrevocably set by the period in which he or she comes of age. Posner came of age when the first wave of game theory and informational economics had already taken hold with its "piling on" of factors. But I came of age in an earlier time. ${ }^{18}$ Professors did not teach whether particular rules could be contracted around, ${ }^{19}$ and most scholarship did not distinguish between optimal default rule setting and optimal setting of mandatory rules. ${ }^{20}$ Although Karl Llewellyn had long ago discussed the difference between "iron" (i.e., mandatory) and "yielding" (i.e., default) rules, ${ }^{21}$ and even though the Uniform Commercial Code and the various editions of the Restatement of Contracts at times included the telltale phrase "unless otherwise agreed,"22 there was not a general recognition in the classroom or in scholarship that the contractibility vel non of a particular rule is often more important than the content of the rule itself. John Langbein tells me that when writing in 1984 about the law of succession, he had to retreat to the little-known Roman law distinction between jus strictum and jus dispositivum to capture whether laws "override or yield to the contrary intentions of the parties." ${ }^{23}$ Until the late 1980 s, we simply lacked a

18. Posner defines the modern cra as having begun about thirty years ago. Posner, supra note 1 , at 829 . I've been on the scene about half that period-arriving largely after the seminal contributions of Goetz and Scott, Robert Cooter, Craswell, Schwartz, Shavell, Anthony Kronman, and Thomas Ulen (although these authors still continue to contribute).

19. See Ian Ayres, Empire or Residue: Competing Visions of the Contractual Canon, 26 FLA. ST. U. L. REV. 897, 910 (1999); lan Ayres \& Robert Gertner, Filling Gaps in Incomplete Contracts: An Economic Theory of Default Rules, 99 Y ALE L.J. 87, 130 (1989).

20. Indeed, many law-and-economics scholars simply modeled contractual problems as they had tort problems: They tricd to discover what rule would maximize the efficiency of a homogenous set of contractors and then argued that this was the efficient rule of law. Of course, without any heterogeneity of contractors, there was not any room in their models for default analysis, because there could be no dispersion in equilibrium contract terms.

21. See generally Alan Schwartz, Karl Llewellyn and the Origins of Contract Theory, in THE JURISPRUDENTIAL FOUNDATIONS OF CORPORATE AND COMMERCIAL LAW 12, 15-19 (Jody S. Kraus \& Steven D. Walt eds., 2000).

22. See, e.g., U.C.C. \$ 2-319 (1995); RESTATEMENT (SECOND) OF CONTRACTS $\$ 302$ (1990).

23. John H. Langbein, The Nonprobate Revolution and the Future of the Law of Succession, 97 HARV. L. REV. 1108,1134 (1984). 
common vocabulary-in part because the academy largely underappreciated the importance of the distinction.

All this has changed. ${ }^{24}$ It has become almost impossible to write a contract article without expressly articulating the default/mandatory dimension of the problem. It is impossible to ignore contractibility in choosing the content of the rule because we now know that the optimal substance for a rule will often be different for rules that are contractible than for those that are not. ${ }^{25}$ And contra to Posner, this revolution has reached out into express lawmaking. For example, the new Uniform Trust Code law expressly and exhaustively attempts to compile all the mandatory rules in an initial section. ${ }^{26}$ This extremely helpful undertaking was not a priority in the past. ${ }^{27}$

But more than just making the default/mandatory dichotomy more visible, the default revolution has clarified when mandatory rules are and are not appropriate and has enhanced lawmakers' tool bag for creatively setting defaults.

\section{Contributions to Analysis of Mandatory Rules}

From early on, there was basic agreement that mandatory restrictions on freedom of contract could only be justified by efforts to protect parties inside the contract (parentalism) or parties outside the contract (externalities) ${ }^{28}$ Important disagreements remained as to the appropriate scope of these "exceptions." But here Posner argues for an exceptionally narrow conception of when mandatory rules might be appropriate:

The premises of economics push in the direction of freedom of contract, and this current can be resisted only with difficulty. If parties are rational, they will enter contracts only when it is in their self-interest, and they will agree only to terms that make them better off. Courts that refused to enforce these terms would make it

24. Dating the change is made easier by its connection to the personal computing revolution. The term "default" almost certainly has a software etymology-for example, a default margin of one inch. Indeed, it may be that the mutability of computer codes illuminated the centrality of mutability for legal codes. See lan Ayres \& Matthew Funk, Marketing Privacy, 20 Y ALE J. ON REG. (forthcoming 2003) (arguing that the value of "eyeballs" for Internet advertising made more visible the value of compensating households for telemarketing advertisements); Lawrence Lessig, The Law of the Horse: What Cyberlaw Might Teach, 113 HARV. L. REV. 501, 505-06 (1999).

25. See Ian Ayres \& Robert Gertner, Majoritarian vs. Minoritarian Defaults, 51 STAN. L. REV. 1591 (1999).

26. UNIF. TRUST CODE $\S 105(\mathrm{~b})$ (2001); see also John H. Langbein, The Uniform Trust Code: Codification of the Law of Trusts in the United States, 15 TR. L. INT'L 66, 76 (2001).

27. Prior to its 2001 revision, the UCC attempted to establish that by default its provisions would be contractible - a default default, so to speak. See U.C.C. § 1-102(3) (1995) ("[T]he effect of provisions of this Act may be varied by agreement except as otherwise provided . ...").

28. See Ayres \& Gertner, supra note 19 , at 88. 
more difficult for future parties to use contracts to enhance their joint well-being. Therefore, courts should enforce the terms of the contract. $^{29}$

The foregoing quote refers to the "premises of economics," but nothing in economics can define what beginning premises or assumptions are empirically reasonable. Posner's strong presumption against the use of mandatory rules relies not on economic analysis but instead on empirical assumptions about the limited capacities of lawmakers. While I, like most contracts scholars, believe that the bulk of contract rules should be contractible, I am more sanguine about the capacity of courts or legislatures. For example, look at how Posner rejects mandatory limits based on substantively unfair terms:

[E]conomists typically argue that courts should not avoid contracts because of the unequal bargaining power of the parties. When contracts appear to have very high price terms, a court could determine only with great difficulty whether the high price is due to market power or fluctuations in the costs of inputs. A high interest rate, for example, could result from the creditor's judgment about the risk of default posed by a particular debtor, and generally courts should defer to such judgments. A determination that the creditor has market power requires an evaluation of the structure of the market, a notoriously difficult enterprise usually reserved for antitrust litigation. $^{30}$

But economists have routinely opined on whether high prices were driven by costs or revenues. For example, Nobel Prize-winning economist George Stigler in 1968 had no trouble concluding that the variation in negotiated car prices could not plausibly be explained by differences in a dealership's expected cost. ${ }^{31}$ And my own automotive empiricism suggests the existence of substantial supracompetitive pricing. ${ }^{32}$ For example, Mark Cohen and $\mathrm{I}$, in analyzing data concerning car loans made by Nissan Motor Acceptance Corporation (NMAC), found that ten percent of NMAC borrowers paid more than a $\$ 1600$ markup on their car loans above the risk-

29. Posner, supra note 1 , at 842 .

30. Id. at 843 .

31. George Stigler rejected the possibility that the observed price dispersion in car sales could be attributed to cost-based differences in the provision of service. He concluded, "[I]t would be metaphysical, and fruitless, to assert that all dispersion is due to heterogeneity." GEORGE J. STIGLER, THE ORGANIZATION OF INDUSTRY 172 (1968).

32. See IAN AYRES, PERVASIVE PREJUDICE (2001). 
adjusted "buy rate" set by the lender. ${ }^{33}$ A court should have no difficulty seeing such practices as a form of price gouging. ${ }^{34}$

But stepping back, it is truly bizarre that Posner would include this argument as part of a criticism of modern economic analysis. The last twenty years have seen a flourishing of new explanations for mandatory rules. The willingness of courts to strike down overreaching contracts is not inconsistent with the modern scholarship, but with premodern laissez-faire arguments of the Chicago School to which the modern scholarship was reacting in large part.

Indeed, Posner himself has contributed a truly original new justification for a mandatory limitation on unfair price. ${ }^{35} \mathrm{He}$ suggested that usury laws might be socially valuable not despite the fact that they make it harder for poor people to get credit, but because they make it harder for poor people to get credit. Posner suggested the possibility of a new externality argument for usury laws. If poor people who default are likely to impose external costs on society-such as going on public assistance-it might be in society's interest to constrain the incentives of the poor to overuse the safety net. Usury laws then might constrain a kind of moral hazard of the poor to avail themselves of social insurance. I view this article as raising just the kind of interesting normative possibility that falls within the center of the modern movement. In the first draft of the essay to which I am responding, Posner concluded that the modern models "do not justify striking down contracts with harsh terms when there is no evidence of fraud or serious information asymmetry.",36 But Posner's own externality model provides an exception that is nowhere cited in his broad indictment of recent scholarship.

More generally, the new scholarship has identified new strategic inefficiencies that might be ameliorated by mandatory rules. These contributions are merely "possibility theorems," but they have deepened our understanding of both externalities and parentalism as grounds for limiting contractual freedom. For example, Kathryn Spier and Michael Whinston have expanded the externality rationale for mandatory rules by showing that

33. Ian Ayres \& Mark Cohen, Supplemental Report on Racial Impact of NMAC's Finance Charge Markup Policy (Aug. 28, 2001) (unpublished report, on file with author).

34. Unconscionability cases set at the retail level often present an easier case for judging supracompetitive price terms than antitrust cases set at the manufacturing level because the transfer price that the retailer pays for the goods (such as a car or a can of peas) more clearly establishes the marginal cost of the item. See lan Ayres \& F. Clayton Miller, "I'll Sell It to You at Cost": Legal Methods To Promote Retail Markup Disclosure, 84 NW. U. L. REv. 1047, 1069 (1990).

35. Eric A. Posner, Contract Law in the Welfare State: A Defense of the Unconscionability Doctrine, Usury Laws, and Related Limitations on the Freedom To Contract, 24 J. LEGAL STUD. 283 (1995).

36. Eric A. Posner, Economic Analysis of Contract Law After Three Decades: Success or Failure? 15 (May 7, 2002) (unpublished manuscript, on file with author). 
supracompensatory damages might be used to improve a seller's bargaining position vis-à-vis a third party-and that mandatory limits on damages might increase social welfare. ${ }^{37}$

More importantly, Philippe Aghion and Benjamin Hermalin have provided a stronger economic rationale for basing mandatory rules on a kind of parentalism to protect parties within the contract from acting inefficiently. ${ }^{38}$ Parentalism restrictions are often driven more by concerns with equity than efficiency (and hence are more controversial for a certain type of economist). But Aghion and Hermalin showed that contractual limits can be justified as a way to stop contracting parties from acting inefficiently-and thus provide an impeccable new justification even for those economists who only care about the total size of the pie and not how it is distributed. The basic idea is that the promisor might agree to pay supracompensatory damages as a way of signaling that she is of higher quality than another potential promisor. The problem is that the low-quality promisor doesn't take this signaling lying down. The low-quality promisor may be willing to mimic the initial attempts of the high-quality promisors to distinguish themselves - which in turn causes the high-quality promisors to offer to be subject to even more draconian punishments if they fail to perform. In equilibrium, the high-quality promisors may find it rational to promise massively inefficient damage terms in order to avoid the tarnish of being lumped together in the promisee's mind with the low-quality promisors. Aghion and Hermalin showed ${ }^{39}$ that a legal limit on damages that forced high- and low-quality promisors to pool could-another possibility theorem-induce a more efficient equilibrium.

To my mind, this is a pretty neat contribution. Contract law caps liquidated damages, and Aghion and Hermalin show why this might be efficient. But Posner is not satisfied: "If we take [the Aghion and Hermalin] argument seriously, we should apply it not only to remedial terms. ${ }^{, 40}$ Posner argues that potential employees might engage in inefficient oversignaling regarding how much schooling they receive, so that by Aghion and Hermalin's logic it might also improve social welfare to restrict

37. Kathryn E. Spier \& Michael D. Whinston, On the Efficiency of Privately Stipulated Damages for Breach of Contract: Entry Barriers, Reliance, and Renegotiation, 26 RAND J. ECON. 180 (1995); see also Aaron S. Edlin, Breach Remedies, in THE NEW PaLgrave DiCTIONARY OF ECONOMICS AND THE LAW 174 (Peter Newman ed., 1998).

38. Philippe Aghion \& Benjamin Hermalin, Legal Restrictions on Private Contracts Can Enhance Efficiency, 6 J.L. ECON. \& ORG. 381 (1990).

39. Their article builds upon the seminal insurance models in Michael Rothschild \& Joseph Stiglitz, Equilibrium in Competitive Insurance Markets: An Essay on the Economics of Imperfect Information, 90 Q.J. ECON. 629 (1976). The same idea can be found in Ian Ayres, The Possibility of Inefficient Corporate Contracts, 60 U. CIN. L. REV. 387 (1991) and even earlier in Samuel J. Rea, Jr., Arm-Breaking, Consumer Credit and Personal Bankruptcy, 22 ECON. INQUIRY 188 (1984).

40. Posner, supra note 1 , at 860 . 
employers' ability to pay higher wages to more educated workers. This argument is not persuasive. Not all slopes are equally slippery. Although inefficient oversignaling can take place in multiple contexts, do we really need to be agnostic as to whether "pound of flesh" damage provisions and diploma bonuses are equally likely to be socially inefficient? I hope not. Legislatures and courts might limit restrictions on contractual freedom to places where they are most likely to produce undesired consequences. In short, while law-and-economics scholars often critique the noncontractible quality of many existing rules, modern scholarship deserves credit for actually identifying rigorous new bases for mandatory contract law.

\section{Contributions to Analysis of Default Rules}

Posner's analysis of default rules strikes a similar theme: "The standard economic analysis of default rules is broadly consistent with judicial practices; courts employ a mix of majoritarian and penalty defaults. But it does no more than rationalize these practices, for there is no way to measure the variables that determine the relative efficiency of the rules." ${ }^{, 41}$ He again complains that the normative analysis of default rule setting is not sufficiently precise to yield determinate policy. I strongly disagree. But before descending to the muck of particulars, it is important to emphasize that "the standard economic analysis" that Posner describes did not exist until fifteen years ago. Prior analysts thought that optimal default rules should mimic the majority's preferences. Again, I see value in making visible the possibility of a different basis for default rule setting and for noticing that, as a descriptive matter, there were information-forcing or penalty defaults. The modern theory certainly does a better job of explaining the existing "mix of majoritarian and penalty defaults" ${ }^{\text {"42 }}$ because the preexisting theory had no way of justifying the practice. ${ }^{43}$

The modern scholarship also has shown that default rule setting can be extraordinarily important. Twenty years ago, scholars who thought about default rule setting would tend to say that not much turned on the choice between alternative defaults because the maximum inefficiency of making the wrong choice would be the cost of contracting around the inefficient

41. Id. at 841 .

42. Id.

43. To be precise, preexisting scholarship did see that contracting around default rules could induce parties to reveal private information, as shown by Hadley v. Baxendale, 156 Eng. Rep. 145 (Ex. 1854). See POSNER, supra note 4, at 114; William Bishop, The Contract-Tort Boundary and the Economics of Insurance, 12 J. LEGAL STUD. 241, 253 (1983); Charles J. Goetz \& Robert E. Scott, Enforcing Promises: An Examination of the Basis of Contract, 89 YALE L.J. 1261, 1299300 (1980). But the prior scholarship had not seen these possibilities as being in tension with the accepted "hypothetical" contract approach to default setting (or as providing a broader theory for default setting). 
rule. We now know this to be wrong. In models with incomplete information, the efficiency loss of choosing an inefficient rule can greatly exceed the nominal private costs of contracting around a default. ${ }^{44}$ Inertia is an important determinant of human action, and a central theorem of modern scholarship is that

[m]ore parties will be covered by a rule if we make that rule a default than will be covered by that rule if we make a different rule the default.... The number of people who fail to contract around a given default is always greater than the number of people who would affirmatively contract for the substantive provision in the shadow of some other rule. This is the iron law of default inertia. ${ }^{45}$

But let us proceed to particulars: Is Posner correct that "there is no way to measure the variables that determine the relative efficiency of the rules"? ${ }^{46}$ Certainly not. Lawmakers can and routinely do use penalty defaults to correct asymmetric ignorance about the law. The contractor who is a repeat player (e.g., the insurance company, the car dealership, or the prosecutor as plea bargainer) is much more likely to know the default rule than the nonrepeat players (e.g., the insured, the car buyer, or the criminal defendant). All this is to say that the contra proferentum presumption is often sound, and modern theory clarifies why this is so.

Or let's look at the two most basic contractual terms-price and quantity. Rob Gertner and I pointed out that the law applied two very different types of defaults-supplying a "reasonable" price, but a "zero" quantity in the case of gaps. We suggested that the first more closely implements a majoritarian rule while the latter more closely implements a penalty default. Do we really need to be normatively agnostic about the common law's choice? No. It is much more difficult for courts to supply majoritarian quantities than majoritarian prices because to determine quantities courts would need to look at the preferences of the particular contracting parties, but would only need to assess the market-wide price to fill a price gap. Parties have an important comparative advantage in filling the quantity gap relative to filling the price gap, and it is reasonable for the law to impose a stronger duty to express quantity.

Besides justifying current practice, the factors identified by modern default analysis provide a credible basis for law reform. For example, applying the Hadley limitation to lost-profit damages so as to give sellers a better incentive to disclose when they are about to earn unexpectedly high profits is likely to produce benefits in both equity and efficiency. Indeed, I

44. Ayres \& Gertner, supra note 17 , at 762 .

45. Ayres \& Gertner, supra note 25 , at 1598.

46. Posner, supra note 1 , at 841 . 
have argued that the law should go further and establish a zero dollar default for lost retail profit damages. If a retailer does not liquidate an amount denominated as lost profits, it should not be able to claim them in later litigation.

Again, the modern analysis has enriched lawmakers' tool bag by identifying a variety of factors that could lead toward utility of nonmajoritarian rules. ${ }^{47}$ Some degree of indeterminacy should be expected because a major theme of the modern scholarship is that there will often be a close horse race between alternative defaults. ${ }^{48}$ But the fact that many horse races are close does not mean that lawmakers will be unable to identify the winners in precisely those contests where there is the most at stake. Asymmetric information problems do not pervasively produce equal strategic inefficiencies across all contract settings. There is no persuasive economic reason to suspect that lawmakers will be unable to identify the circumstances where the problems are the greatest and respond accordingly with information-forcing rules (or possibly with mandatory rules, which, as discussed above, can be seen as information-dampening rules that restrict the ability of contractors to signal information credibly).

\section{B. The Importance of Renegotiation}

A second fundamental contribution of the modern economic scholarship is a more systematic analysis of the impact of renegotiation on the optimal design of legal rules. A naive Holmesian might think that when changed circumstances make performance less profitable, a promisor must confront the dyadic choice of performing or paying damages. But we now know that the promisor often has not two, but three choices to consider: performing, paying damages, or renegotiating her way out of the original performance obligation. ${ }^{49}$

Appreciating the importance of this renegotiation option has profound implications for our understanding of how contractors will behave. For example, imagine that like the Peevyhouses, you have just received a promise from the Garland Coal company to move back top soil after strip mining. ${ }^{50}$ Would you as promisee prefer breech damages of $\$ 25,000$ or of $\$ 35,000$ ? It's elementary that potential plaintiffs would generally be better off with higher potential damages. But this is not necessarily the case when

47. See Ayres \& Gertner, supra note 25 , at 1592 (identifying five factors).

48. See Bernard S. Black, Is Corporate Law Trivial?: A Political and Economic Analysis, 84 Nw. U. L. REV. 542, 542-45 (1990) (suggesting that even mandatory rules may have effects only on equilibrium).

49. See Ayres \& Madison, supra note 16, at 106.

50. The details of the case can be found in Judith L. Maute, Peevyhouse v. Garland Coal \& Mining Co. Revisited: The Ballad of Willie and Lucille, 89 Nw. U. L. REV. 1341 (1995). 
we take into account the possibility of renegotiation. If moving the dirt back is going to cost the coal company $\$ 30,000$ (but only benefit you by $\$ 2000$ ), then you might be better off with lower damages. Here's why. If damages are expected to be $\$ 35,000$, then the coal company is likely to threaten performance as a way to negotiate a lower damage amount. The coal company may in essence say, "If you don't let me out of the deal for $\$ 16,000$, I promise you that I will perform the contract-so you can forget about ever seeing $\$ 35,000$ in damages. Let me out for $\$ 16,000$, or I'll perform." When damages are high, this threat is credible, because if renegotiations break down, the coal company will prefer performance to breach. But if the damages are lower, the plaintiff has much stronger bargaining power during renegotiation. If damages are only $\$ 25,000$ and the renegotiations break down, the coal company would prefer to breach and pay damages - so there is little reason for the promisee to accept less than $\$ 25,000$.

Prior analysts (including judges) had seen the possibility of renegotiation based on threats to perform, ${ }^{51}$ but modern analysis has shown when the threats are more likely to be credible and how performance threats can turn our normal intuitions about damages on their heads: Plaintiffs can be made better off by lower damages, while defendants can be made better off by higher damages.

Appreciating the renegotiation possibility also has overturned preexisting intuitions about the overreliance problem. The first generation of economic analysis focused on whether different damage measures would induce efficient breach decisions. ${ }^{52}$ But more modern scholarship has focused on how contract remedies affect the investments that contractors make in reliance on the contract. The focus on the efficiency of reliance decisions instead of on breach decisions is driven in large part by the possibility of renegotiation. When renegotiation is costless, we know from the Coase Theorem that promises will be performed only when performance is efficient regardless of the background legal remedy. When damages are draconian (à la specific performance), promisors will buy their way out of their duties to perform. When damages are relatively paltry (à la

51. See N. Ind. Pub. Serv. Co. v. Carbon County Coal Co., 799 F.2d 265, 279 (7th Cir. 1986) ("[B]y offering [the seller] more than contract damages ... [the buyer] could induce [the seller] to discharge the contract and release [the buyer] to buy cheaper coal.... Probably, therefore, [the seller] is seeking specific performance in order to have bargaining leverage with [the buyer] ....").

52. See, e.g., Robert L. Birmingham, Breach of Contract, Damage Measures, and Economic Efficiency, 24 RUTGERS L. REV. 273, 285-86 (1970) (arguing that restitution and reliance damages encourage efficient breach); Richard Craswell, Contract Remedies, Renegotiation, and the Theory of Efficient Breach, 61 S. CAL. L. REV. 629, 669 (1988); Edlin, supra note 37, at 174; Lewis A. Kornhauser, An Introduction to the Economic Analysis of Contract Remedies, 57 U. COLO. L. REV. 683 (1986); Steven Shavell, Damages Measures for Breach of Contract, 11 BELL J. ECON. $466(1980)$. 
reliance), promisees will bribe promisors to perform efficiently. As Aaron Edlin writes in a Palgrave entry that repays careful reading: "[T]he bulk of the recent literature ... assume[s] . . that parties can negotiate costlessly to an ex post efficient outcome before the breach decision; that way overall efficiency is determined by the efficiency of ex ante reliance, since ex post trade is always efficient." ${ }^{\text {53 }}$

The first systematic analysis of the reliance decision by Shavell and Rogerson, dating from the early 1980 s, showed that all standard remedies frequently promote overinvestment in reliance by promisees. ${ }^{54}$ Cooter and Eisenberg then showed that restricting expectation damages (to the amount that would be necessary if the promisee had engaged in efficient reliance) could solve the overreliance problem and that the common-law mitigation principle might crudely work to implement an analogous type of restriction. ${ }^{55}$

But in the $1990 \mathrm{~s}$, a number of articles suggested that the overinvestment result could be qualified or reversed by new types of contracts or new types of investments. ${ }^{56}$ The problem of overreliance is caused in essence by the way traditional remedies compensate promisees for reliance even when performance turns out to be inefficient. If promisees' reliance investments are effectively insured in the case of breach, they may not take into account the possibility that marginal reliance investments are unwarranted by the possibility of nonperformance. But Edlin and others have shown that it is possible to counteract the implicit reliance subsidy of promisees by either manipulating the contract provisions (1) to control the identity of which side is more likely to breach, or (2) to create intentionally the possibility that the promisor will be able to hold up the promisee and claim part of the benefit of the promisee's reliance investments. ${ }^{57}$

53. Edlin, supra note 37, at 175. Alan Schwartz and Joel Watson have recently shown how the results of renegotiation models change when we relax the assumption of costless renegotiation. See ALAN SCHWARTZ \& JOEL WATSON, ECONOMIC AND LEGAL ASPECTS OF COSTLY RECONTRACTING (UCSD Econ. Discussion Paper No. 2000-05, 2000).

54. See William P. Rogerson, Efficient Reliance and Damage Measures for Breach of Contract, 15 RAND J. ECON. 39, 41 (1984); Shavell, supra note 52, at 472.

55. See Robert Cooter, Unity in Tort, Coniract, and Property: The Model of Precaution, 73 CAL. L. REV. 1, 1-2 (1985); Robert Cooter \& Melvin Aron Eisenberg, Damages for Breach of Contract, 73 CAL. L. REV, 1432, 1464 (1985).

56. E.g., Philippe Aghion et al., Renegotiation Design with Unverifiable Information, 62 ECONOMETRICA 257 (1994); Yeon-Koo Che \& Tai-Yeong Chung, Contract Damages and Cooperative Investments, 30 RAND J. ECON. 84 (1999); Yeon-Koo Che \& Donald B. Hausch, Cooperative Investments and the Value of Contracting, 89 AM. ECON. REV. 125 (1999); TaiYeong Chung, Incomplete Contracts, Specific Investments, and Risk Sharing, 58 REV. ECON. STUD. 1031 (1991); W. Bentley MacLeod \& James M. Malcomson, Investments, Holdup and the Form of Market Contracts, 83 AM. ECON. REV. 811 (1993).

57. See, e.g., Aaron S. Edlin, Cadillac Contracts and Up-Front Payments: Efficient Investment Under Expectation Damages, 12 J.L. ECON. \& ORG. 98 (1996); Aaron S. Edlin \& 
Somewhat surprisingly, the new scholarship has turned a deeply accepted tenet of the Coase Theorem on its head. Naive Coaseans tend to think that the original endowment of entitlement should not affect allocative efficiency. But the modern contract analysis shows that even when renegotiation is perfect, the initial assignment of rights can importantly influence the incentives of parties to invest in unverifiable (and therefore noncontractible) amounts of reliance. ${ }^{58}$ If a promisee ends up valuing performance less than the promisor's cost of performance, it must be the case that at least one of the parties will have an incentive to bribe its way out of the contract. But prior analysis did not appreciate that the parties' ex ante agreement could endogenously determine the identity of who would have to bribe whom and that manipulating the identity of the briber could have important impacts on the efficient breach. ${ }^{59}$

Moving from the Holmesian dyadic to a triadic view of contractual performance-where promisors have the choice of performing, breaching, or negotiating their way out of the contract-pays big dividends. We now know that in some contexts, a major goal of an initial agreement should be to set up the appropriate threat points for a subsequent renegotiation.

Stepping back, I believe that this Part's brief survey of contributions is sufficient to show that modern scholarship has been clarifying. It has appropriately destabilized misplaced acceptance of prior consensus. And at times it has suggested specific normative conclusions about the content of contract law. But to be fair, Posner's normative criticism also includes the claim of judicial "paralysis" - that judges have reacted to the "distressingly open-ended" and intricate implications of modern scholarship by "simply ignor[ing] them." 60 Even if modern scholarship has produced real normative contributions, Posner might still be correct that the scholarship has failed because judges and legislators have ignored it.

Posner is right that modern scholarship has not had a large impact on how judges or legislators decide law. Judges do not cite to the scholarship, and with very few exceptions they arc probably ignorant about its results-

Stephan Reichelstein, Holdups, Standard Breach Remedies and Optimal Investment, 86 AM. ECON. REV. 478 (1996).

58. The finding of an influence from entitlement assignment on noncontractible investments does not, however, contradict the Coase Theorem, because the assumption of noncontractibility with regard to reliance investment is an important form of transactional friction that can produce allocation effects.

59. In addition, Che and Chung's analysis of "cooperative investments" has enriched our understanding of an important new type of investment decision that now has to be considered in any full treatment of reliance efficiency. See Che \& Chung, supra note 56; Che \& Hausch, supra note 56 . The standard analysis focused on "self-investments"-i.e., seller investments that reduce the cost of performance or buyer investments that increase the benefit of purchasing. But Che and Chung pointed out real world examples where sellers might make investments that increase a buyer's benefit of purchasing or where buyers might make investments that reduce a seller's cost of performing, thereby showing that standard damage remedies can induce too little reliance.

60. Posner, supra note 1 , at 855. 
even ignorant about whether they are promulgating mandatory or default rules. But here Posner is setting the bar very high. Gentle reader, when was the last time one of your own articles changed the law? With the exception of antitrust law, ${ }^{61}$ there are very few areas of modern jurisprudence where lawmakers are deeply concerned with the view of modern scholarship. The disconnect between lawmaking and legal academia is well documented. ${ }^{62}$

And besides, fifteen or twenty years is simply not enough time to run this experiment. The current crop of law students is much more likely to appreciate the centrality of the default/mandatory dimension of lawmaking. There is now a more common vocabulary. When the next generation comes to power, we will have a fairer test of whether what is now the "modern" scholarship fails to persuade.

Once we have a new generation of lawmakers who have been exposed to the "new" learning, Posner might predict that they will reject the normative advice as being distressingly open-ended. ${ }^{63}$ But let me be clear. I have argued that some of the open-endedness is an important contribution of the new scholarship. Instead of reflexively accepting the almost universal superiority of default rules, the new scholarship has thrown into question whether mandatory rules may have a broader role to play. And instead of reflexively accepting that majoritarian or hypothetical defaults are presumptively efficient, the new scholarship suggests that other bases for default choice may better further consequentialist goals. The destabilizing contributions of modern scholarship usefully advise lawmakers to be prudent. The fact that modern scholarship does not provide ready answers to every question, far from scaring judges away, may be an invitation for judges and other lawmakers to weigh pragmatically a variety of possible alternatives (and possible effects). This may be the best we can hope for and is in the end more likely to "conduce to the sweet" than a Panglossian presumption that (almost) all rules should be defaults and (almost) all defaults should be majoritarian. ${ }^{64}$

I, for one, predict that the exhaustive listing of mandatory rules by the new Uniform Trust Code law-which, by the way, I take as an important impact of modern scholarship upon the law-is just the beginning of a trend to develop a more explicit jurisprudence of contractibility. When Posner's

61. William H. Page, The Chicago School and the Evolution of Antitrust: Characterization, Antitrust Injury, and Evidentiary Sufficiency, 75 VA. L. REV. 1221 (1989). But see Alvin Klevorick, The Current State of the Law and Economics of Predatory Pricing, 83 AM. ECON. REV. PAPERS \& PROC. 162 (1993) (showing modern scholarship's lack of influence on judicial decisionmaking).

62. See Anthony Kronman, The Lost Lawyer (1993); Harty T. Edwards, The Growing Disjunction Between Legal Education and the Legal Profession, 91 MICH. L. REV. 34 (1992).

63. Or we may find that they reject the efficiency advice because they are "captured" by other interest groups - even those favoring equity.

64. CANDIDE, THE Musical (Sony Records 1991). Pangloss teaches that "all bitter things conduce to sweet." Id. 
students become judges, they are more likely to emphasize when future parties retain the ability-by using different words-to overturn a judicial precedent privately.

\section{ONE POSSIBLE FUtURE: OPT-OUT RULES}

While the foregoing suffices to show that modern scholarship has to date made important normative contributions, Posner's evolutionary critique is harder to disprove. Even if George Bailey has had a wonderful life up until now, it might nonetheless be the right time for him to cut the tree. $^{65}$ Less poetically, it's harder to disprove the claim that modern economic analysis of contracts has played itself out. But let me try-by suggesting that there are still very basic questions that have not been systematically analyzed.

To my mind, there are three basic tasks of contract law: (1) to determine the substantive content of contract rules, (2) to determine whether private action can supplant this substance, and (3) to determine how the private parties can contract around it. ${ }^{66}$ Let's call these the content task, the contractibility task, and the opt-out task. We now know a great deal about the first two tasks. And as emphasized above, a major contribution of modern scholarship was to show that the content and contractibility tasks are not separable. The optimal content of a rule is contingent on whether or not the rule is contractible. Majoritarianism as a basis for establishing the content makes great sense when one is determining the content of mandatory rules. I tell my students that this is how a "tort head" tends to analyze the law-because tort law is primarily a system of mandatory rules. But we now know that determining the optimal content of contractible rules requires a consideration of a variety of factors

65. Interestingly, in the movie It's a Wonderful Life, the angel Clarence uses an indirect mode of persuasion-a counterfactual about the past to convince the protagonist not to cut short his future life. Bailey might have responded to the angel's argument by saying, "You're right, Clarence. I'm glad I was born and have lived up until now, but prospectively I think I'm better off dead." In contrast, Charles Dickens's A Christmas Carol and Nikos Kazantzakis's The Last Temptation of Christ rely more strongly on direct persuasion revealing to the protagonist what will happen prospectively if he continues along a certain path.

The reference to "cutting the tree" comes from the classic economic problem of determining when it is the appropriate time to cut down a tree. For profit maximizers, the answer is when the market value of the tree starts growing more slowly than the interest rate. High rates of past growth do not mean that it is inappropriate to cut a tree that is prospectively expected to grow at an inefficiently slow rate.

66. The last task might alternatively be characterized as determining the legal consequences of attempting to contract around the substance of the initial rule. This is a broader characterization because even if the law determines the substance to be not contractible (i.e., mandatory), the law must still determine the appropriate response to private parties' attempts to contract around the rule. Courts often apply one of two legal responses, either penalizing one or both parties for attempting to contract around, or altematively merely nullifying or ignoring the attempt to contract around the rule. See Ayres, supra note 19, at 902. 
that have been identified by the modern literature. ${ }^{67}$ A "contract head" needs to think differently than a "tort head."

We still know very little, however, about the opt-out task. While there now have been not just articles but full symposia focusing exclusively on whether rules should be mandatory or default (the contractibility task) ${ }^{68}$ and how to set defaults (the content task), ${ }^{69}$ there has been no sustained theorizing about how law should regulate the process of contracting around. ${ }^{70} \mathrm{~A}$ strong indication that there is an important gap in the literature is that we do not even have a well-accepted term for the question to be studied. Just as we did not have a standardized term for the mandatory/default dichotomy fifteen years ago, we still do not have standardized terms for those legal rules that establish the necessary and sufficient conditions for contracting around. Let me call these legal rules "opt-out" rules. ${ }^{71}$

I do not think that the economic analysis has played itself out because there are still very basic unanswered questions about how the law should set opt-out rules.

Should the law merely try to minimize the transaction cost of contracting around defaults, or should it also be concerned about the error costs of misinterpreting potential attempts at opting out? The tension between these two norms is raised ubiquitously in computer programming whenever the user is asked a second time, "Do you really want to delete this file?"

Should the law ever try to discourage (or "tax") opt-out? Instead of setting either a simple mandatory or default rule, could there be a value to

67. See Barry E. Adler, The Questionable Ascent of Hadley v. Baxendale, 51 STAN. L. REV. 1547 (1999); Ayres \& Gertner, supra note 25; Randy E. Barnett, The Sound of Silence: Default Rules and Contractual Consent, 78 VA. L. REV. 821,822 (1992); Lucian Arye Bebchuk \& Steven Shavell, Information and the Scope of Liability for Breach of Contract: The Rule of Hadley $\mathrm{v}$. Baxendale, 7 J.L. ECON. \& ORG. 284 (1991); Richard Craswell, Contract Law, Default Rules, and the Philosophy of Promising, 88 MICH. L. REV. 489, 503 (1989); Richard Craswell, Property Rules and Liability Rules in Unconscionability and Related Doctrines, 60 U. CHI. L. REV. 1, 15 n.28 (1993); Jason Scott Johnston, Strategic Bargaining and the Economic Theory of Contract Default Rules, 100 YaLE L.J. 615 (1990).

68. See Lucian Arye Bebchuk, The Debate on Contractual Freedom in Corporate Law, 89 COLUM. L. REV. 1395 (1989) (summarizing symposium articles on the topic of mandatory terms in a corporate law system of default rules).

69. See, e.g., Symposium, Default Rules and Contractual Consent, 3 S. CAL. INTERDISC. L.J. 1 (1993); sources cited supra note 37.

70. Rob Gertner and I promised to provide such a thcory in the second half of our original Yale article but fell woefully short of delivering on the promise.

71. The term "opt-out" is used more commonly to describe a default rule of potential liability (where the promisor has to opt out affirmatively to nullify the potential for liability), in contradistinction to "opt-in" defaults where the promisor has to opt in affirmatively to create the potential for liability. See, e.g., Robert R. Biggerstaff, State Courts and the Telephone Consumer Protection Act of 1991: Must States Opt-In? Can States Opt-Out?, 33 CONN. L. REV. 407 (2001); John A. Buchman, Opt In, Opt Out or Do Nothing-That Is the Question, BuS. L. TODAY, Jan.Feb. 1996 , at 48 . 
having "sticky" defaults" ${ }^{72}$ not to assure contractors' intents but to dissuade contractors with only weak preferences from separating out of the lawmaker's preferred pool?

Should courts as a matter of course tell the losing side in interpretive contract disputes how it could prospectively alter the contract to reach its desired result? ${ }^{73}$ In classic cases like Peevyhouse v. Garland Coal ${ }^{74}$ and Jacob and Youngs v. Kent, ${ }^{75}$ courts reject attempts to opt out of defaults and uphold the potential for opt out while failing to specify safe harbor language that would be sufficient.

How should lawmakers optimally deploy statutory and common law "menus,", "safe harbors,", "shibboleths,"78 and "affirmative choice",79 conditions?

At the moment there are neither satisfying answers for these questions nor overarching theories about how to structure opt-out rules. And, indeed, it is not necessarily true that an economist will provide the answers. ${ }^{80}$ One thing is clear, however-that this opt-out task of law is not separable from the content or contractibility tasks. Information-forcing defaults, for example, are much more likely to need opt-out rules that require the disclosure of information in order to opt out. And of course we would want different opt-out rules to govern mandatory rules (where by assumption we want to discourage opt-out) than for default rules (where we are likely to be at least neutral as to whether the parties opt out).

\section{CONCLUSION}

In sum, Posner has leveled three different criticisms at the modern economic analysis of contracts: a descriptive critique that the scholarship

72. See Ayres \& Gertner, supra note 19 , at 125 (discussing the possible channeling function of such sticky defaults).

73. I have argued that the answer to this question is "yes." Ian Ayres, Three Proposals To Harness Private Information in Contract, 21 HARV. J.L. \& PUB. POL'Y 135 (1997). But in thinking about the second question, $\mathrm{I}$ am in the process of qualifying that answer.

74. 382 P.2d 109 (Okla. 1962); see also supra text accompanying note 50.

75. 129 N.E. 889 (N.Y. 1931).

76. The modem literature has suggested that express statutory menus of alternative provisions may enhance efficiency at times. See Ayres \& Gertner, supra note 17.

77. A "safe harbor" opt-out rule is a sufficient condition for opting out. See, e.g., U.C.C. $\$ 2-316$ (1995) (" $[\mathrm{U}] \mathrm{nless}$ the circumstances indicate otherwise, all implied warranties are excluded by expressions like 'as is' ....").

78. A "shibboleth" opt-out rule is a necessary condition for opting out. An example is a UCC provision that comes close to requiring that waivers of the implied warranty of merchantability use the word "merchantability" and be conspicuous. See U.C.C. § 2-316(2) (1995).

79. An affirmative choice rule is a type of penalty default that forces contractors to make an affirmative choice in order to create a contract. For example, corporate organizers must affirmatively choose the number and identity of directors in their articles of incorporation. MODEL BUS. CORP. ACT $\S 7.21$ (1985).

80. But I hope to try. 
fails to describe or predict the content of current law, a normative critique that the scholarship fails to "provide a solid basis for criticizing and reforming contract law, ${ }^{, 81}$ and an implicit evolutionary critique that the scholarship has run out of things to say. Posner's descriptive critique is misplaced. Modern scholarship has never been about trying to describe or predict current law. His normative critique is overblown. While Posner is correct that much of the modern scholarship is based on stylized models with results that turn on particular parameter values, he underappreciates the normative importance of "possibility" theorems. Modern scholarship has contributed by showing that the accepted determinacy of prior normative analysis is unsustainable. Moreover, the factors identified by modern literature have generated affirmative policy proposals (such as extending the Hadley foreseeability limitation to seller's lost-profit damages).

But Posner's evolutionary critique may stand on a stronger footing. All valuable schools of inquiry at some point in time tend to reach diminishing marginal returns. The economic analysis of tort law, for example, is widely conceded to have reached a point of "maturity" where it is difficult to find basic untheorized questions for study. And maybe - despite my arguments about opt-out rules - the same is taking place, or about to take place, with regard to the economics of contracts. I join Posner in welcoming and predicting a shift from the theoretical to the empirical. ${ }^{82}$

But instead of debating the future, it's better for us to wait and see. Methodology pieces like this also are subject to the very criticisms that Posner levels at modern scholarship—-they don't predict current law, they don't provide a basis for critiquing current law, and they quickly play themselves out.

A few years back, Posner and I participated in a Wisconsin Law Review symposium comparing economic and sociological approaches to law. Posner wisely eschewed writing an ungrounded piece on methodology and instead published what to my mind was the most valuable contribution of the symposium-an analysis of gratuitous contracts. ${ }^{83}$ In contrast, I dyspeptically complained about the limited value of publishing method pieces, stating that "I generally believe that ungrounded discussions of methodology are not useful. I don't 'do' method—or at least I don't do method well. ... Better to have scholars from different disciplines attack a

81. Posner, supra note 1 , at 830 .

82. A similar shift from the theoretical to the empirical has already occurred with regard to applied game-theoretic analysis. See, e.g., Douglas W. Allen \& Dcan Lueck, The Nature of the Farm, 41 J.L. \& ECON. 343, 344 (1998).

83. Eric A. Posner, Altruism, Status, and Trust in the Law of Gifts and Gratuitous Promises, 1997 WIS. L. REV. 567. 
particular problem, and then assess which methodology produces the best purchase." ${ }^{84}$

These are still my beliefs.

84. Ian Ayres, Never Confuse Efficiency with a Liver Complaint, 1997 WIS. L. REV. 503, 503.

HeinOnline -- 112 Yale L.J. 901 2002-2003

Imaged with the Permission of Yale Law Journal 
HeinOnline -- 112 Yale L.J. 902 2002-2003 Imaged with the Permission of Yale Law Journal 